\title{
The Effect of Corrosive Environment on Geopolymer Concrete Tensile Strength
}

\author{
Ridho Bayuaji ${ }^{1,}$, Sigit Darmawan ${ }^{1}$, Nur Ahmad Husin ${ }^{1}$, Boedi Wibowo ${ }^{1}$, Srie Subekti ${ }^{1}$, \\ Mohd Mustafa Al Bakri Abdullah" ${ }^{2}$, Totok Ruki Biyanto ${ }^{3}$ \\ ${ }^{1}$ Civil Engineering Department, Institut Teknologi Sepuluh Nopember, Indonesia \\ ${ }^{2}$ Center of Excellence Geopolymer and Green Technology (CEGeoGTech), Universiti Malaysia Perlis \\ (UniMAP), Malaysia \\ ${ }^{3}$ Physic Engineering Department, Institut Teknologi Sepuluh Nopember, Indonesia
}

\begin{abstract}
This study has the purpose to explore the potential of geopolymer concrete tensile strength in particular on the effects of corrosive environments. Geopolymer concrete, concrete technology used no OPC that has advantages, one of which is durability, especially for corrosive seawater environment. In addition, geopolymer concrete with polymerization mechanism does not require large energy consumption or an environmentally friendly concept. Geopolymer concrete in this study is using a type $\mathrm{C}$ fly ash from PT. International Power Mitsui Operation \& Maintenence Indonesia (IPMOMI) Paiton. The type of alkaline activator used $\mathrm{NaOH}$ (14 molar) and $\mathrm{Na}_{2} \mathrm{SiO}_{3}$. Coarse and fine aggregate used are local aggregate. Geopolymer concrete molded test specimen with dimensions of $(10 \times 20) \mathrm{cm}$ cylinder, further heating and without heating, then maintained at room temperature and seawater up to 28 days. Then to determine the mechanical properties, the tensile strength testing is done with reference. This result of study indicates the curing of geopolymer concrete at $60^{\circ} \mathrm{C}$ for 24 hours to raise the tensile strength of geopolymer concrete.
\end{abstract}

\section{Introduction}

The challenges to address the potential in Indonesia, which has sea area larger than the land area. It requires infrastructure that capable of supporting mobility between islands with the concept of sustainability. Normal concrete as a structural material currently still needs improvement to challenge the durability properties against seawater environment. Therefore, it is necessary to develop alternative structural materials that have better durability. In addition, community environmentalists have warned that one of the contributors of $\mathrm{CO}_{2}$ is high enough portland cement industry [1].

Studies and research which address the challenges above are continued to be developed; the concept of the mechanism of pozzolan materials [2-4] partially substitute cement is to build extra compounds Calcium Silicate Hydrates (CSHs). These compounds are the source of strength in the concrete with the hydration process. On the other hand, geopolymer concrete is a green technology which is currently being developed [5-11] for the material

\footnotetext{
*Corresponding author: bayuaji@ce.its.ac.id
} 
structure [12]. The main factor that becomes the appeal of geopolymer concrete is the polymerization process, the process of transforming material alumino-silicate oxide and alkaline activator into polysilicate product that has high mechanical strength without using cement. Moreover, in a previous study showed that the geopolymer concrete resistant to sulfuric and hydrochloric acid. Resistance properties are greatly influenced by the nature of the strong alkaline solution, treatment conditions, and the composition of the base material $[13,14]$. Durability geopolymer concrete in corrosive environments has a compressive strength which does also have a good correlation with its tensile strength. As it is known that the normal concrete has a good and consistent correlation to compressive strength tensile strength. Therefore, this study has the purpose to explore the potential of geopolymer concrete tensile strength in particular on the effects of corrosive environments.

\section{Methodology}

Methodology to achieve the objectives of this study used an experimental method which is carried out in the Laboratory of Building Materials and Structures. Type alkaline activator used was $\mathrm{NaOH}$ (14 molar) and $\mathrm{Na}_{2} \mathrm{SiO}_{3}$ and fly ash are used come from PT IPMOMI Paiton with type C. Coarse aggregate used is local aggregates with a maximum diameter of $10 \mathrm{~mm}$. Natural sand is used as a fine aggregate. The composition of geopolymer concrete building blocks to make $1 \mathrm{~m}^{3}$ of fly ash is composed of $630 \mathrm{~kg}, 1,260 \mathrm{~kg}$ of gravel, sand $840 \mathrm{~kg}, 108$ $\mathrm{kg} \mathrm{NaOH}, \mathrm{Na}_{2} \mathrm{SiO}_{3} 162 \mathrm{~kg}$, Superpalsticizier $18.9 \mathrm{~kg}, 12.6 \mathrm{~kg}$ of water. Tensile strength testing use standard ASTM C 496-94. Before being tested for tensile strength, geopolymer concrete specimen molded with dimensions of $(10 \times 20) \mathrm{cm}$ cylinder, further treatment as described in Table 1.

Table 1. Curing Conditions on Geopolymer Concrete.

\begin{tabular}{|l|l|}
\hline \multicolumn{1}{|c|}{ Combination } & \multicolumn{1}{c|}{ Information } \\
\hline 1. Oven-Room (O-R) & $\begin{array}{l}\text { After opening of the mold, the specimen cured at } 60^{\circ} \mathrm{C} \text { for } 24 \text { hours } \\
\text { and subsequently cured at room temperature } 27-30^{\circ} \mathrm{C} \text { and an } \\
\text { average humidity of } 60-70 \% .\end{array}$ \\
\hline 2. Oven-Sea (O-L) & $\begin{array}{l}\text { After opening of the mold, the specimen cured at } 60^{\circ} \mathrm{C} \text { for } 24 \text { hours } \\
\text { and subsequently cured in a corrosive environment with a } \\
\text { temperature of } 24-34^{\circ} \mathrm{C} \text { and an average humidity of } 50-92 \% .\end{array}$ \\
\hline $\begin{array}{l}\text { 3. Without Oven-Room } \\
\text { (TO-R) }\end{array}$ & $\begin{array}{l}\text { After opening the mold, then cured at room temperature } 27-30^{\circ} \mathrm{C} \\
\text { and an average humidity of } 60-70 \% .\end{array}$ \\
\hline $\begin{array}{l}\text { 4. Without Oven-Sea (TO-L) } \\
\text { After opening the mold, then cured in a corrosive environment with } \\
\text { a temperature of } 24-34^{\circ} \mathrm{C} \text { and an average humidity of } 50-92 \% .\end{array}$ \\
\hline
\end{tabular}

\section{Result and discussion}

The test results obtained geopolymer concrete tensile strength is shown in Table 2. The compressive strength test was conducted on material testing laboratory ITS FTSP civil engineering diploma. The results of the testing of the strong sides of geopolymer concrete are as follows: 
Table 2. Test Results of Geopolymer Concrete Tensile Strength.

\begin{tabular}{|c|c|c|c|c|c|}
\hline No & Test Item Code & Curing Code & $\begin{array}{c}\text { Test Strength } \\
\text { (N) }\end{array}$ & $\begin{array}{l}\text { Tensile Strength } \\
\left(\mathbf{N} / \mathbf{m m}^{2}\right)\end{array}$ & $\begin{array}{l}\text { Average } \\
\left(\mathbf{N} / \mathbf{m m}^{2}\right)\end{array}$ \\
\hline 1 & $1 \mathrm{~A}$ & O-R & 146000 & 4.65 & \multirow{3}{*}{4.55} \\
\hline 2 & 1B & O-R & 149000 & 4.74 & \\
\hline 3 & $1 \mathrm{C}$ & $\mathrm{O}-\mathrm{R}$ & 134000 & 4.27 & \\
\hline 4 & $2 \mathrm{~A}$ & $\mathrm{O}-\mathrm{L}$ & 136000 & 4.33 & \multirow{3}{*}{4.92} \\
\hline 5 & 2B & $\mathrm{O}-\mathrm{L}$ & 150000 & 4.77 & \\
\hline 6 & $2 \mathrm{C}$ & $\mathrm{O}-\mathrm{L}$ & 178000 & 5.67 & \\
\hline 7 & $3 \mathrm{~A}$ & TO-R & 93000 & 2.96 & \multirow{3}{*}{3.16} \\
\hline 8 & $3 \mathrm{~B}$ & TO-R & 105000 & 3.34 & \\
\hline 9 & $3 \mathrm{C}$ & TO-R & 100000 & 3.18 & \\
\hline 10 & $4 \mathrm{~A}$ & TO-L & 101000 & 3.21 & \multirow{3}{*}{3.62} \\
\hline 11 & 4B & TO-L & 114000 & 3.63 & \\
\hline 12 & $4 \mathrm{C}$ & TO-L & 126000 & 4.01 & \\
\hline
\end{tabular}

Tensile strength average of the test specimen cured with a temperature of $60^{\circ} \mathrm{C}$ for 24 hours and then placed at room temperature $(\mathrm{O}-\mathrm{R})$ have a strong sides that are lower than the specimen cured with a temperature of $60^{\circ} \mathrm{C}$ for 24 hours and then soaked in sea water (O-L). Immersion in sea water raises the tensile strength of geopolymer concrete at $8.15 \%$. The specimens cured at room temperature (TO-R) has a tensile strength which is lower than the cured test specimens at room temperature and then cured in sea water (TO-L). Immersion in seawater raises the tensile strength as much as $14.43 \%$ of geopolymer concrete. The average compressive strength of the test specimen cured with a temperature of $60^{\circ} \mathrm{C}$ for 24 hours and then placed at room temperature $(\mathrm{O}-\mathrm{R})$ have a strong sides higher than specimens cured at room temperature (TO-R). Curing with a temperature of $60^{\circ} \mathrm{C}$ for 24 hours to raise tensile strength as much as $43.96 \%$ of geopolymer concrete. Average tensile strength of the test specimen cured with a temperature of $60^{\circ} \mathrm{C}$ for 24 hours and then immersed in sea water (O-L) have a tensile strength higher than specimens cured at room temperature and then cured in sea water (TO-L). Curing with a temperature of $60^{\circ} \mathrm{C}$ for 24 hours raises tensile strength as much as $36.07 \%$ of geopolymer concrete. Reddy et al [15] found similar trend in their experimental program were accelerated corrosion test in natural sea water.

\section{Conclusion}

This study suggests that the curing of geopolymer concrete at $60^{\circ} \mathrm{C}$ for 24 hours showed better tensile strength than cured at room temperature. Tensile strength of geopolymer concrete under the influence of chloride ion-containing environment of the sea showed better results than those cured at room temperature.

The authors would like to thank RISTEK-DIKTI and LPPM ITS for provided financial assistance to complete this laboratory research grants. In addition, the support of Laboratory of Material and Building Structure of Diploma Civil Engineering Program ITS is greatly appreciated. 


\section{References}

1. J. Davidovits, World Resour. Rev., 6, 263 (1994)

2. R. Bayuaji, R. Kurniawan, A. Yasin, H. A. Fatoni, F. Lutfi, IOP Conference Series: Materials Science and Engineering, 012014 (2016)

3. R. Bayuaji, Jurnal Teknologi, 75 (2015)

4. A.M. Neville, Properties of Concrete (Longman, 1995)

5. W. Supriadi, R. Bayuaji, R. Burhan, H. Fansuri, Mater. Sci. Forum, 841 (2016)

6. A. Kusbiantoro, N. Rahman, S.C. Chin, R. Bayu Aji, Mater. Sci. Forum, 841,16 (2016)

7. H. Fansuri, A. Fatmawati, W. P. Utomo, W. Supriadi, R. Bayuaji, Mater. Sci. Forum, 841 (2016)

8. J. J. Ekaputri, Mater. Sci. Forum, 841 (2016)

9. L.Y. Dwijayanti, J.J. Ekaputri, R. Bayuaji, Mater. Sci. Forum, 841,140 (2016)

10. M.S.D. Ridho Bayuaji, Boedi Wibowo, Nur Ahmad Husin, Srie Subekti, Januarti Jaya Ekaputri, Applied Mechanics and Materials, 754, 400 (2015)

11. J.J. Ekaputri, M. Bahrul Ulum, B. Ridho, T.E. Susanto, M.M. Al Bakri Abdullah, Applied Mechanics and Materials, 754, 320 (2015)

12. R. Bayuaji, M.F. Nuruddin, S. Francis, J. Ekaputri, S. Junaedi, H. Fansuri, Mater. Sci. Forum, 803, 49 (2015)

13. A. Allahverdi, International Cement Conference (Iran, 2004)

14. D. Hardjito, S.E. Wallah, D. M.J. Sumajouw, B.V. Rangan, Australian Journal of Structural Engineering, 6, 1 (2005)

15. D.V. Reddy, J.B. Edouard, K. Sobhan, J. Mater. Civ. Eng., 25, 781 (2013) 